\title{
FACTORS EFFECTING THE DECOMPENSATION OF CHRONIC HEART FAILURE IN THE ELDERLY
}

\author{
V.N. Larina*, B.Ya. Bart, E.A. Vartanyan \\ The Russian National Research Medical University named after N.I. Pirogov. \\ Ostrovitianova ul. 1, Moscow, 117997 Russia \\ Factors effecting the decompensation of chronic heart failure in the elderly \\ V.N. Larina*, B.Ya. Bart, E.A. Vartanyan \\ The Russian National Research Medical University named after N.I. Pirogov. Ostrovitianova ul. 1, Moscow, 117997 Russia
}

Aim. To identify risk factors of decompensation of chronic heart failure (CHF) and related hospitalization in elderly outpatients.

Material and methods. The total of 248 patients aged 60-85 years with CHF NYHA class II-IV were enrolled into the study. The first group consisted of 87 (35. $1 \%$ ) patients who required hospitalization due to CHF decompensation during the follow-up, the second group - of 161 patients without need for hospital admission. All the patients had undergone clinical and laboratory examination, estimation of CHF severity by the Scale of clinical state, assessment of quality of life and 6 -minute walk test (6MWT), echocardiography.

Results. Patients were matched for age, gender, disability occurrence, education level, body mass index, quality of life, hemodynamic parameters, incidence rates of anemia, diabetes mellitus and atrial fibrillation. CHF was more severe in patients who had required hospitalization $(p<0.001)$, they were more often diagnosed with left ventricular aneurysm ( $p=0.001)$, chronic kidney disease $(p=0.001)$, left ventricular ejection fraction (LVEF) $<35 \%(p<0.001)$, history of stroke $(p<0.001)$, III-IV degree mitral regurgitation ( $p=0.007)$, hyperuricemia ( $p<0.001)$, lower exercise tolerance $(p=0.007)$ compared with patients without hospitalization. Higher functional class of CHF $(O R=0.29 ; 95 \% \mathrm{Cl} 0.13-0.69 ; \mathrm{p}=0.003), \mathrm{LVEF}<35 \%(\mathrm{OR} 0.37 ; 95 \%$ $\mathrm{Cl} 0.18-0.76 ; p=0.007)$, chronic kidney disease $(\mathrm{OR}=0.29 ; 95 \% \mathrm{Cl} 0.13-0.68 ; p=0.004)$ and hyperuricemia $(\mathrm{OR}=0.23 ; 95 \% \mathrm{Cl} 0.10-0.50 ; p<0.001)$ were shown to be independent risk factors of CHF decompensation that required hospital admission in elderly patients.

Conclusuion. High FC of CHF, low LVEF, hyperuricemia and renal dysfunction play a key role in CHF decompensation and related hospitalization in elderly patients

Key words: chronic heart failure, hospitalization, elderly patients.

Rational Pharmacother. Card. 2013;9(1):15-24

\section{Факторы, влияющие на декомпенсацию хронической сердечной недостаточности у лиц пожилого возраста \\ В.Н. Ларина*, Б.Я. Барт, Е.А. Вартанян \\ Российский национальный исследовательский медицинский университет имени Н.И. Пирогова. 117997, Москва, ул. Островитянова, 1}

Цель. Выявить факторы, повышающие риск декомпенсации хронической сердечной недостаточности (ХСН) и связанных с ней госпитализаций у пожилых больных, наблюдающихся в поликлинических условиях.

Материал и методы. В исследование были включены 248 больных в возрасте от 60 до 85 лет с XCH II-IV функционального класса (ФК) по NYHА. Первую группу составили 87 $(35,1 \%)$ больных, которым в процессе наблюдения потребовалась госпитализация в связи с декомпенсацией ХСН, вторую группу составил 161 больной, не нуждавшийся в ней. Всем больным проводили клинико-лабораторное обследование, оценивали тяжесть ХСН по шкале оценки клинических состояний, качество жизни, осуществляли тест с 6-минутной ходьбой, эхокардиографию.

Результаты. Больные двух групп были сопоставимы по возрасту, полу, наличию инвалидности, уровню образования, индексу массы тела, качеству жизни, гемодинамическим показателям, частоте встречаемости анемии, сахарного диабета и фибрилляции предсердий. Течение ХСН было более тяжёлое у больных, которым потребовалась госпитализация $(p<0,001)$, у них чаще выявлялись аневризма левого желудочка (ЛЖ) $(p=0,001)$, хроническая болезнь почек $($ ХБП) ( $(p=0,001)$, фракция выброса левого желудочка (ФВ ЛЖ)<35\% $(p<0,001)$, острое нарушение мозгового кровообращения в анамнезе $(p<0,001)$, митральная регургитация $3-4$ степени ( $p=0,007)$, гиперурикемия ( $<<0,001)$, была ниже физическая толерантность $(p=0,007)$ - в отличие от больных без госпитализаций. Высокий ФК ХСН [отношение шансов (ОШ) 0,29; $95 \%$ доверительный интервал (ДИ) 0,13-0,69; $p=0,003]$, ФВ ЛЖ <35\% (ОШ 0,37; 95\%ДИ 0,18-0,76; $p=0,007)$, ХБП (ОШ 0,29; 95\%ДИ 0,13-0,68; $=0,004)$ и гиперурикемия (ОШ 0,23; $95 \%$ ДИ 0,10-0,50; $<<0,001)$ оказались независимыми факторами декомпенсации ХСН, потребовавшей госпитализации пожилых больных.

Заключение. Высокий ФК ХСН, низкая ФВ ЛЖ, гиперурикемия и сниженная функция почек играют решающую роль в декомпенсации ХСН и связанной с ней госпитализации пожилых больных.

Ключевые слова: хроническая сердечная недостаточность, госпитализация, пожилые больные.

РФК 2013;9(1):15-24

*Corresponding author (Автор, ответственный за переписку): larinav@mail.ru

Population aging as well as increased incidence of cardiovascular disease result in steady growth of chronic heart failure (CHF), that is now accounts for 7\% throughout European part of Russian Federation (RF) [1]. CHF prevalence correlates with age: it makes $1.0 \%$ at age $50-59$ and $10-20 \%$ at age 70-80 years [2-5]. $65.5 \%$ of CHF patients in European part of RF are between 60 and 79 years old [5]. CHF is not only associated with high morbidity but is also one of the main reasons for hospital admission especially in the elderly [6-8]. Increase in incidence rate of hospitalization for $\mathrm{CHF}$ among the elderly is expected at an early date [9]. However, factors influencing negatively the disease course have not been formulated yet. Answers to these and some other questions are of great scientific and practical

\section{Authors' information:}

Vera N. Larina - PhD, MD, Professor of Chair of Outpatient Therapy №1, Faculty of General Medicine, the Russian National Research Medical University named after N.I. Pirogov

Boris Y. Bart - PhD, MD, Professor, Head of the same Chair

Elena A. Vartanyan - PhD, MD, Associate Professor of the same Chair
Постарение населения и нарастание случаев сердечнососудистых заболеваний приводят к неуклонному росту частоты возникновения хронической сердечной недостаточности (ХCH), распространённость которой в Европейской части Российской Федерации (РФ) составляет 7\% [1]. Возраст коррелируется с частотой этого заболевания: в возрасте от 50 до 59 лет распространённость XСН составляет 1,0\%, в возрасте 70-80 лет - 10-20\% [2-5]. В Европейской части РФ 65,5\% больных ХСН - это лица в возрасте от 60 до 79 лет [5]. ХСН ассоциируется не только с высокой заболеваемостью, но и является одной из ведущих причин госпитализаций больных, особенно в пожилом возрасте [68]. В ближайшем будущем у пожилых больных ожидается увеличение частоты госпитализаций в связи с ХCH [9]. Несмотря на то, что XCH представляет собой серьёзную проблему в здравоохранении, факторы, неблагоприятно
Сведения об авторах:

Ларина Вера Николаевна - д.м.н., профессор кафедры поликлинической терапии №1 лечебного факультета РНИМУ им. Н.И. Пирогова Барт Борис Яковлевич - д.м.Н., профессор, заведующий той же кафедрой

Вартанян Елена Алексеевна - К.м.Н., доцент той же кафедры 
interest as they can facilitate CHF patients' management in out-patient clinics. This was the grounds for the study.

The aim of the study. To identify risk factors of decompensation of $\mathrm{CHF}$ and related hospitalization in elderly outpatients.

\section{Material and methods}

The total of 248 patients aged 60-85 years with $\mathrm{CHF}$ symptoms were enrolled into the study. The inclusion criteria were the follows: NYHA class II-IV CHF due to ischemic heart disease (IHD) and/or arterial hypertension; stable disease course (absence of hospitalizations for CHF decompensation during preceding 3 months); informed consent for the study participation. The exclusion criteria were the follows: asymptomatic CHF (NYHA class I); rheumatic valve disease; infective endocarditis; myocardial infarction or unstable angina pectoris during preceding 3 months; life expectancy less than 3 years.

Patients with diagnosed CHF were assigned to " $\mathrm{Di}$ agnostic clinical centre №1 of Moscow City Health Department" by primary care physicians and cardiologists of outpatient clinics. The study protocol was approved by the local Ethics Committee. The followup duration was from 1 to 12 years. We registered cases of $\mathrm{CHF}$ decompensation, incidence rate of related hospitalizations and mortality rate. All the patients had undergone clinical examination, evaluation of quality of life with the "Minnesota Living With Heart Failure Questionnaire". CHF symptoms severity was estimated using the Scale of clinical state (SCS), exercise tolerance - by 6 -minute walk test (6MWT). Glucose, creatinine, urea and uric acid serum levels were tested as well. Hyperuricemia was diagnosed at uric acid level $\geqslant 360 \mathrm{mcmol} / \mathrm{l}[10]$. Glomerular filtration rate (GFR) was calculated by MDRD formula [11]. Chronic kidney disease (CKD) was diagnosed at GFR $<60 \mathrm{ml} / \mathrm{min} / 1.73 \mathrm{~m}^{2}$ [12]. Echocardiography test at rest was performed using one-dimensional (M), two-dimensional (B) and Doppler-modes (pulsed-wave and continuous wave) in standard positions by generally accepted procedure $(H$. Feigenbaum, 1986). Ejection fraction (LV EF) was estimated by Simpson procedure in all the patients.

During dose ranging the patients were examined every 3-5 days depending on heart failure severity in accordance to National Guidelines on CHF diagnosis and treatment, and then - every 4- 6 weeks throughout the whole study. After the follow-up completion the patients were divided into two groups according to presence or absence of hospitalizations. влияющие на течение заболевания, окончательно не сформулированы. Ответы на эти и ряд других вопросов представляют большой научный и практический интерес и могут способствовать оптимизации ведения больных XСН, наблюдающихся в поликлинических условиях, что и послужило основанием для проведения настоящего исследования.

Цель исследования. Выявить факторы, повышающие риск декомпенсации XСН и связанных с ней госпитализаций у пожилых больных, наблюдающихся в поликлинических условиях.

\section{Материал и методы}

В исследование были включены 248 больных в возрасте от 60 до 85 лет с симптомами XСН. Критерии включения: XCH II-IV ФК по классификации NYHA, развившейся вследствие ишемической болезни сердца (ИБС) и/или артериальной гипертонии (АГ); стабильное течение заболевания (отсутствие госпитализаций по поводу декомпенсации XCH в течение предшествующих 3 мес); информированное согласие на добровольное участие в исследовании. Критерии исключения: бессимптомная XCH (I ФК по NYHA); ревматический порок сердца; инфекционный эндокардит; инфаркт миокарда и нестабильная стенокардия в течение последних 3 мес перед исследованием; предполагаемая продолжительность жизни менее 3 лет.

При постановке диагноза ХСН больные были направлены участковыми терапевтами и кардиологами поликлиник для коррекции медикаментозной терапии. Протокол исследования одобрен локальным Этическим комитетом. Наблюдение за больными проводилось в ГБУЗ г. Москвы «Диагностический клинический центр №1 Департамента Здравоохранения г. Москвы». Длительность наблюдения составила от 1 до 12 лет. В течение периода наблюдения за больными регистрировались случаи декомпенсации XСН, связанные с ней госпитализации и летальный исход. Всем больным проводилось клиническое обследование, оценивалось качество жизни с помощью опросника «Жизнь больных с хронической сердечной недостаточностью» Миннесотского университета, тяжесть симптомов ХCH оценивалась при помощи шкалы оценки клинического состояния (ШОКС), переносимость физической нагрузки - с помощью теста с 6-ти минутной ходьбой (6MWT). В сыворотке крови определяли содержание глюкозы, креатинина, мочевины и мочевой кислоты. Гиперурикемия диагностировалась при уровне мочевой кислоты $\geqslant 360$ мкмоль/л [10]. Скорость клубочковой фильтрации (СКФ) рассчитывалась по формуле MDRD [1 1]. Хроническую болезнь почек (ХБП) диагностировали при уровне СКФ ниже 60 мл/мин/1,73 м² [12]. Эхокардиография (ЭхоКГ) в покое проводилась в одномерном (М-режиме), двухмерном (В-режиме) и допплеровских режимах (импульсно-волновом и постоянно-волновом) , в стандартных позициях по общепринятой методике H. Feigenbaum (1986). Всем больным определяли фракцию выброса (ФВ ЛЖ) методом Симпсона, из верхушечной позиции на 4 и 2 камеры. 
The data were analyzed by software packages SPSS 16.0 and Statistica 6.0. We tested normality of the data and presented them as median (Me) and the 25 -th and 75 -th percentiles. To compare two independent variables Mann-Whitney rank $\mathrm{U}$-test was used. Discrete variables were presented as a percent of the total amount of patients in a group. To compare such variables contingency tables with $\chi^{2}$ test were used with correction to continuity. In cases when a number of observations did not exceed 5 in one table cell, Fisher's exact test was used. Cox proportional hazard model was used to evaluate connection of possible risk factors with adverse outcome. Multivariate analysis was preceded by univariate one. Multivariate regression analysis included both variables with $p<0.1$ at univariate analysis and indices that could have been connected with a studied outcome in accordance with the data of previous research. Multivariate regression analysis was carried out by step-by-step method. At that we primarily selected an index that most significantly correlated with a studied outcome. Next variables were only included if their addition to the already selected factors revealed significance of the contribution at the level of $\alpha \leqslant 0.1$. Taking into account values of the selected variables we have built the time curves of adverse outcomes occurrence (Kaplan Meier curves) with analysis of the significance of differences by logrank test. Distinctions were considered significant at twoway $p<0.05$.

\section{Results}

The total of 87 (35.1\%) patients have been admitted to hospital for CHF decompensation throughout the study forming the first group. 25 of these 87 (28.7\%) patients were readmitted. The second group (patients who did not require hospitalization) included 161 patients. The main characteristics of the patients, data about risk factors and medical treatment are presented in table 1 .

Patients of the both groups were matched for age, gender, disability occurrence, education level, body mass index, quality of life, hemodynamic parameters, incidence rates of anemia, diabetes mellitus and atrial fibrillation. Patients, who had required hospital admission, revealed more severe $\mathrm{CHF}$ then those who were not hospitalized [7 (5-11) and 5 (4-7) scores by SCS, respectively; $p<0.001]$. The patients of the first group more often revealed left ventricle aneurism, chronic kidney disease (CKD) and history of stroke. Simultaneous presence of two severe vascular complications such as previous myocardial infarction and stroke
При поступлении под наше наблюдение больные осматривались в зависимости от тяжести сердечной недостаточности каждые 3-5 дней при подборе медикаментозной терапии согласно Национальным рекомендациям по диагностике и лечению XCH, затем - с частотой 1 раз в 4-6 нед на протяжении всего периода наблюдения. По окончании периода наблюдения больные были разделены на 2 группы в зависимости от наличия или отсутствия госпитализаций.

Статистическую обработку данных проводили с использованием пакетов программ SPSS 16.0 и Statistica 6.0. Данные проверялись на «нормальность» и представлены В виде медианы (Ме) и 25-й и 75-й перцентилей. При сравнении двух независимых величин применялся ранговый U-критерий Манна-Уитни. Дискретные переменные представлены в виде процента от общего числа больных в группе. Для их сравнения применялся анализ таблиц сопряжённости с применением критерия $\chi^{2}$ с поправкой на непрерывность или точный тест Фишера, когда количество наблюдений в одной из ячеек таблицы не превышало 5. Связь возможных факторов риска с неблагоприятным исходом оценивали в модели пропорционального риска Кокса. Многофакторному анализу предшествовал однофакторный. В многофакторный регрессионный анализ включали переменные, для которых значения критерия статистической значимости при однофакторном анализе составляли $p<0,1$, а также признаки, которые могли быть связаны с изучаемым исходом по данным предшествующих исследований. Многофакторный регрессионный анализ выполняли пошаговым методом. При этом первоначально выделяли признак, наиболее тесно связанный с изучаемым исходом. Последующие переменные включали только в случае, если их добавление к уже отобранным факторам демонстрировало значимость вклада на уровне $\alpha \leqslant 0,1$. С учётом выявленных значений отобранных переменных построены кривые времени наступления неблагоприятного исхода (кривые Каплана-Мейера) с анализом достоверности различий при помощи теста «лог-ранк». Различия считали статистически значимыми при значениях двустороннего $p<0,05$.

\section{Результаты}

За период наблюдения было госпитализировано 87 $(35,1 \%)$ больных по поводу декомпенсации XCH, составивших первую группу. У 25 из 87 (28,7\%) больных госпитализация была неоднократной. Вторая группа (пациенты, не нуждавшиеся в госпитализации) включала 161 больного. Основные характеристики больных, данные по факторам риска и медикаментозная терапия представлены в табл. 1.

Больные двух групп были сопоставимы по возрасту, полу, наличию инвалидности, уровню образования, индексу массы тела, качеству жизни, гемодинамическим показателям, частоте встречаемости анемии, сахарного диабета и фибрилляции предсердий. Течение ХCH было более тяжёлое у больных, которым потребовалась госпитализация, в отличие от больных 
Table 2. Structural and functional heart indices in CHF patients

Таблица 2. Структурно-функциональные показатели сердца у больных XСH

\begin{tabular}{|c|c|c|c|}
\hline $\begin{array}{l}\text { Parameter / } \\
\text { Параметр }\end{array}$ & $\begin{array}{c}\text { Hospital patients / } \\
\text { Наличие госпитализаций }(\mathrm{n}=87)\end{array}$ & $\begin{array}{l}\text { Outpatients / } \\
\text { Отсутствие госпитализаций (n=161) }\end{array}$ & $\mathrm{p}$ \\
\hline LV EF / ФВЛЖ, \% & $40(30-50)$ & $50(40-58)$ & $<0.001$ \\
\hline $\mathrm{EDD}, \mathrm{cm} / \mathrm{KД}, \mathrm{CM}$ & $6.1(4.8-6.1)$ & $5.7(4.8-6.3)$ & 0.004 \\
\hline ESD, $\mathrm{cm} / \mathrm{KCP}, \mathrm{CM}$ & $4.5(3.9-5.0)$ & $4.0(3.5-4.6)$ & 0.001 \\
\hline 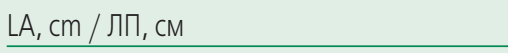 & $4.4(4.2-4.7)$ & $4.2(4.1-4.5)$ & 0.002 \\
\hline EDV, $\mathrm{ml} /$ КДО, мл & $167(110-198)$ & $135(100-192)$ & 0.052 \\
\hline ESV, cm / КСО, мл & $102(55-130)$ & $66(43-110)$ & 0.013 \\
\hline IVS, cm / MЖП, сM & $1.13(1.0-1.2)$ & $1.12(1.0-1.2)$ & 0.408 \\
\hline PW, cm / ЗСЛЖ, см & $1.1(1.0-1.1)$ & $1(1.0-1.1)$ & 0.266 \\
\hline PA SP, mm Hg / Рсист ЛА, мм рт.ст. & $34(30-40)$ & $32(28-35)$ & 0.013 \\
\hline MR of III-IV degree / MP 3-4 степени, n (\%) & $38(43.7)$ & $43(26.7)$ & 0.007 \\
\hline \multicolumn{4}{|c|}{$\begin{array}{l}\text { Data are presented as median with } 25 \text { and } 75 \text { percentiles or as n (\%). p - significance of distinctions at the two groups comparison; LV EF - left ventricle (LV) ejection fraction; EDD } \\
\text { - LV end-diastolic diameter; ESD - LV end-systolic diameter; LA - left atrium; EDV - LV end-diastolic volume; ESV - LV end-systolic volume; IVS - interventricular septum; PW - pos- } \\
\text { terior wall; PA SP - pulmonary artery systolic pressure; MR - mitral regurgitation }\end{array}$} \\
\hline \multicolumn{4}{|c|}{$\begin{array}{l}\text { Данные представлены в виде медианы 25-го и 75-го перцентилей или в виде n (\%). p - значимость различий при сравнении больных двух групп; КДР - конечно-диасто- } \\
\text { лический размер ЛЖ; КСР - конечно-систолический размер; ЛП - размер левого предсердия; КДО - конечно-диастолический объём ЛЖ; КСО - конечно-систолический } \\
\text { объём ЛЖ; МЖП - межжелудочковая перегородка; ЗСЛЖ - задняя стенка ЛЖ; Рсист ЛА - систолическое давление в лёгочной артерии; МР - митральная регургитация }\end{array}$} \\
\hline
\end{tabular}

Table 3. Laboratory parameters in CHF patients

Таблица 3. Лабораторные показатели больных ХCH

\begin{tabular}{|c|c|c|c|}
\hline $\begin{array}{l}\text { Parameters / } \\
\text { Показатели }\end{array}$ & $\begin{array}{c}\text { Hospital patients / } \\
\text { Наличие госпитализаций }(n=87)\end{array}$ & $\begin{array}{c}\text { Outpatients / } \\
\text { Отсутствие госпитализаций (n=161) }\end{array}$ & $p$ \\
\hline Hemoglobin, g/dl / Гемоглобин, г/дл & $13.7(12.7-14.8)$ & $13.7(12.9-14.9)$ & 0.934 \\
\hline Total cholesterol, mmol/l / Общий холестерин, ммоль/л & $5.7(4.9-6.3)$ & $5.6(4.8-6.4)$ & 0.651 \\
\hline Creatinine, mcmol/l / Креатинин, мкмоль/л & $112(97.5-136.8)$ & $99.8(89.0-116.6)$ & 0.001 \\
\hline Urea, mmol/l / Мочевина, ммоль/л & $7.7(6.4-9.3)$ & $6.8(5.9-8.7)$ & 0.050 \\
\hline $\mathrm{GFR}, \mathrm{ml} / \mathrm{min} / 1,73 \mathrm{~m}^{2} /$ СКФ, мл/мин/1,73м² & $53(44-59)$ & $58(53-68)$ & 0.001 \\
\hline Glucose, mmol/l / Глюкоза, ммоль/л & $6.23(5.4-7.2)$ & $5.7(5.3-6.3)$ & 0.054 \\
\hline Uric acid, mcmol/l / Мочевая кислота, мкмоль/л & $477(346-554)$ & $393(327-499)$ & 0.003 \\
\hline \multicolumn{4}{|c|}{ Data are presented as median with 25 and 75 percentiles. GFR - glomerular filtration rate } \\
\hline \multicolumn{4}{|c|}{ Данные представлены в виде медианы 25-го и 75-го перцентилей. СКФ - скорость клубочковой фильтрации } \\
\hline
\end{tabular}

Table 4. Risk-factors for hospitalization in elderly CHF patients

Таблица 4. Факторы риска госпитализации пожилых больных с ХCH

\begin{tabular}{|c|c|c|}
\hline Index / Показатель & OR (95\% Cl) / ОШ (95\% дИ) & p \\
\hline NYHA class III-IV / III-IV ФK по NYHA & $4.94(2.45-9.93)$ & $<0.001$ \\
\hline LV EF $<35 \% /$ ФВ ЛЖ $<35 \%$ & $2.08(1.09-3.97)$ & 0.026 \\
\hline Mitral regurgitation of 3-4 degree / Митральная регургитация 3-4 степени & $1.95(1.13-3.38)$ & 0.017 \\
\hline CКD / ХБП & $2.81(1.41-5.60)$ & 0.003 \\
\hline History of stroke / OHMK & $0.32(0.17-0.62)$ & $<0.001$ \\
\hline Hyperuricemia / Гиперурикемия & $1.87(1.01-3.49)$ & 0.048 \\
\hline
\end{tabular}

gurgitation (MR) of III-IV degree, low LV EF including $L V E F<35 \%$ ( $n=39 ; 44.8 \%$ in the first group vs $\mathrm{n}=31 ; 13 \%$ in the second one; $\mathrm{p}<0.001)$ as compared with the second group (table 2 ).
По результатам ЭхоКГ у больных, которым потребовалась госпитализация, выявлялись увеличенные размеры и объёмы ЛЖ и ЛП, чаще имелась митральная регургитация 3-4 степени, более низкая ФВ ЛЖ, и среди них чаще встреча- 


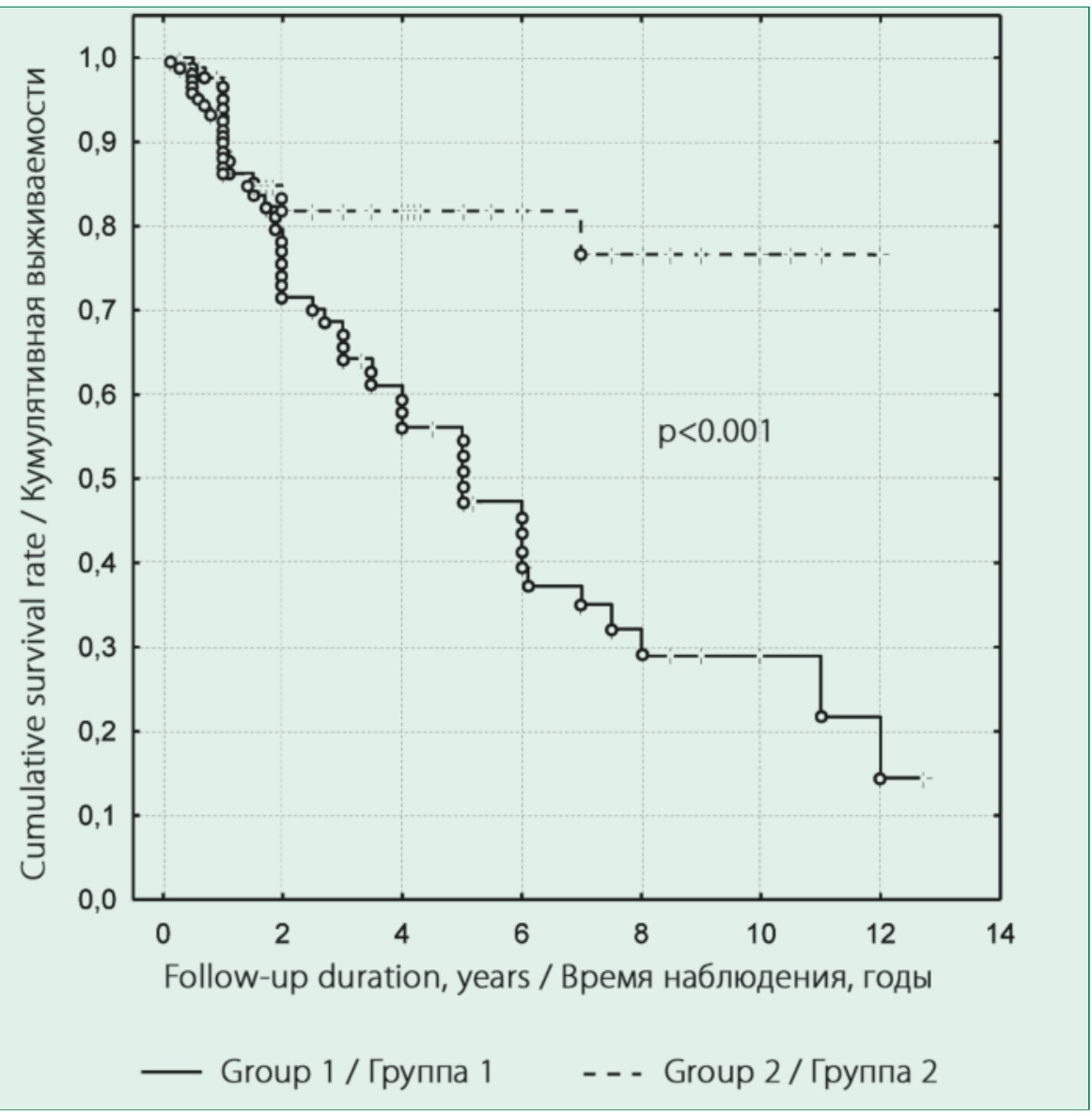

Figure 1. Time curves of adverse outcome occurrence in elderly CHF patients with (group 1) and without (group 2) hospitalizations ( $p<0.001)$

Рисунок 1. Кривые времени наступления неблагоприятного исхода у пожилых больных с XCH, у которых были (группа 1) и не были (группа 2) указания на госпитализации $(p<0,001)$

Levels of hemoglobin, total cholesterol and glucose were similar in patients of the both groups, at that the first group patients in comparison with the second group demonstrated renal dysfunction and hyperuricemia more often (table 3 ). Table 4 shows risk factors for hospital admission in elderly CHF patients in accordance with univariate analysis. As for multivariate regression analysis results the following parameters were shown to be independent prognostic factors for hospital admission due to CHF decompensation: high FC of CHF (odds ratio (OR) 0.29; 95\% confidence interval $(\mathrm{Cl}) 0.13-0.69 ; \mathrm{p}=0.003)$, LV EF<35\% (OR $0.37 ; 95 \% \mathrm{Cl}$ 0.18-0.76; $\mathrm{p}=0.007$ ), CKD (OR 0.29; 95\% Cl 0.13-0.68; $p=0.004)$ and hyperuricemia (OR $0.23 ; 95 \% \mathrm{Cl}$ $0.10-0.50 ; p<0.001)$. The analysis also revealed lower survival rate in hospital patients as compared with out-patients ( $p<0.001) .47$ patients $(54 \%)$ of the first group and 21 (13\%) of the second one had died during the follow-up. Time curves of adverse outcome occurrence in admitted and non-admitted CHF patients are shown on figure 1. лись больные с ФВ лЖ<35\% $(n=39 ; 44,8 \%)$, чем во второй группе $(n=31 ; 13 \% ; p<0,001)$ (табл. 2).

По данным лабораторного исследования у больных двух групп уровни гемоглобина, общего холестерина, глюкозы были сопоставимы, в то время как среди больных первой группы, в отличие от больных второй группы, чаще встречалась сниженная функция почек и гиперурикемия (табл. 3). Факторы риска госпитализации пожилых больных XСН по данным однофакторного регрессионного анализа представлены в табл. 4. Согласно результатам многофакторного регрессионного анализа независимыми прогностическими факторами декомпенсации XCH, потребовавшей госпитализации пожилых больных, явились высокий ФК ХСН [отношение шансов (ОШ) 0,29, 95\% доверительный интервал (ДИ) $0,13-0,69 ; p=0,003], Ф В$ лж $<35 \%$ (ОШ 0,37; 95\%ди $0,18-0,76 ; p=0,007)$, ХБП (ОШ 0,$29 ; \quad 95 \%$ ДИ $0,13-0,68$; $\mathrm{p}=0,004)$ и гиперурикемия (ОШ 0,23; 95\%ДИ 0,10-0,50; $p<0,001)$. В результате проведенного анализа были получены данные о худшей выживаемости больных со случаями госпитализации по сравнению с негоспитализированными больными $(p<0,001)$. За период наблюдения в первой группе умерло 47 (54\%), во второй - 21 (13\%) больной. Кривые времени наступления неблагоприятного исхода у больных с ХCH, имевших и не имевших госпитализации, представлены на рис. 1.

\section{Обсуждение}

Одной из ведущих проблем современной кардиологии является профилактика осложнений сердечно-сосудистых заболеваний, в том числе и ХСН, поскольку уровень госпитализаций, инвалидности и летального исхода при этом заболевании существенно не снижаются. В связи с этим необходимо выявление факторов, позволяющих своевременно оценить риск не только развития XСН, но и неблагоприятного течения развившегося заболевания, что позволяет корректировать тактику ведения больного. Проведенное нами исследование было направлено на выявление факторов, способствующих декомпенсации XСН и связанной с ней госпитализации больных в возрасте 60 лет и старше, наблю- 


\section{Discussion}

Taking into account non-declining level of hospital admissions, disability and mortality in CHF patients prevention of complications of heart diseases, including CHF, is of great importance. That's why, it is necessary to reveal factors that allow timely estimation of not only the CHF development risk but also the risk of unfavorable course of the main disease, what allows correction of patients management. Our study was aimed at detection of the factors that promote CHF decompensation and following hospitalization in outpatients $\geqslant 60$ years old, because CHF decompensation is the leading cause of hospital admission in such patients $[13,14]$. Our study confirmed that the main factors correlated with CHF decompensation and following hospitalization were parameters that were reflecting the severity of the disease. According to univariate analysis data these factors were as follows: low LV EF, high FC of CHF, history of stroke, renal dysfunction, MR of III-IV degree and hyperuricemia; while according to multivariate analysis data they were: high FC of CHF (OR 0.29), $L V E F<35 \%$ (OR 0.37), CKD (OR 0.29) and hyperuricemia (OR 0.23 ). $35.1 \%$ of all the patients were hospitalized during 1.5 (0.9-4.0) years follow-up because of $\mathrm{CHF}$ decompensation. We have noted that hospitalization incidence rate increased at CHF severity augmentation: thus, there were $14.9 \%$ of II FC and $85.1 \%$ of III-IV FC among hospitalized CHF patients. Patients with LV EF $<35 \%$ were also admitted more often than those with higher LV EF $(p<0.001)$. $31 \%$ of the first group patients and $13 \%$ of the second one had history of stroke $(p<0.001)$, while combination of previous $\mathrm{MI}$ and stroke was detected in $22.9 \%$ of the first group patients and in $9.3 \%$ of the second one $(p=0.003)$. History of stroke predetermines severe course of disease in patients with cardiovascular diseases, in particular CHF. Our study confirmed these data.

Severe mitral regurgitation being not only the result of LV remodeling but also the reason for it, demonstrates essential clinical significance as a risk factor for CHF decompensation and progression. It leads to volume overload which in turn increases myocardial wall stress, intensifies expression of neurohormones, cytokines, matrix metalloproteases, initiates molecular ways of signal transmission concerned with apoptosis and cardiomyocytes death, induces remodeling and thus contributes to heart failure progression $[15,16]$. MR of III-IV degree at echocardiography was found in $43.7 \%$ of our patients who further required hospitalization and in $26.7 \%$ who did not ( $p=0.007$ ). So, according to our data MR of III-IV degree together with FC of CHF, LV EF and history of stroke is a risk fac- дающихся в поликлинических условиях, поскольку именно декомпенсация XCH является ведущей причиной госпитализации таких больных [13, 14]. В нашем исследовании основными факторами, связанными с декомпенсацией ХСН и госпитализацией больных, оказались параметры, отражающие тяжесть заболевания. Согласно данным однофакторного анализа ими были: низкая ФВ ЛЖ, высокий ФК, ОНМК в анамнезе, почечная дисфункция, МР 3-4 степени и гиперурикемия, по результатам многофакторного анализа - высокий ФК XСН (ОШ 0,29), ФВ ЛЖ <35\% (ОШ $0,37)$, ХБП (ОШ 0,29) и гиперурикемия (ОШ 0,23). В течение 1,5 (0,9-4) лет было госпитализировано 35,1\% наблюдавшихся нами больных по поводу декомпенсации XCH. Мы отметили, что частота госпитализаций повышалась по мере нарастания тяжести XСН: при II ФК было госпитализировано 14,9\%, при III-IV ФК - 85,1\% больных. Среди больных, имевших ФВ ЛЖ $<35 \%$, также было госпитализировано больше больных, чем с более высокой ФВ ЛЖ $(p<0,001)$. Перенесенное ОНМК встречалось у $31 \%$ больных первой и у $13 \%$ - второй группы $(p<0,001)$, а комбинация ОИМ и ОНМК встречалась у 22,9\% больных первой группы и у 9,3\% - второй группы $(p=0,003)$. Наличие ОНМК в анамнезе предопределяет тяжёлое течение заболевания у больных, имеющих сердечно-сосудистые заболевания, в частности, ХCH, что мы и наблюдали на примере наших больных.

Среди факторов, способствующих декомпенсации и прогрессированию ХСН, важное клиническое значение имеет выраженная митральная регургитация, которая является не только результатом ремоделирования ЛЖ, но и его причиной. Объёмная перегрузка при наличии митральной регургитации увеличивает напряжение в стенке сердечной мышцы, усиливает экспрессию нейрогормонов, цитокинов, матриксных металлопротеаз, запускает молекулярные пути передачи сигналов, связанных с системой апоптоза и гибелью кардиомиоцитов, индуцирует ремоделирование и способствует прогрессированию симптомов сердечной недостаточности $[15,16]$. Митральная регургитация 3-4 степени выявлялась при ЭхоКГ-исследовании у 43,7\% больных, находившихся под нашим наблюдением, и которым потребовалась госпитализация, и у $26,7 \%$ - без неё $(p=0,007)$. Согласно полученным нами данным наряду с ФК ХСН, ФВ ЛЖ и ОНМК в анамнезе фактором риска декомпенсации ХCH также является митральная регургитация 3-4 степени, что согласуется с данными других исследователей. Последняя встречается у 18,9-39\% больных после перенесенного инфаркта миокарда ЛЖ, и её наличие неблагоприятно сказывается на течении заболевания и прогнозе больных с ХCH [17-19].

Помимо общепринятых факторов риска неблагоприятного течения и исхода при ХСН у больных, которым потребовалась госпитализация, чаще встречалась сниженная функция почек (79,3\%) по сравнению с больными без госпитализации (55,3\%). Значимость почечной дисфункции 
tor for $\mathrm{CHF}$ decompensation, which is consistent with other researchers' data. MR of III-IV degree was revealed in $18.9-39 \%$ of patients with previous myocardial infarction and influenced negatively on CHF course and prognosis [17-19].

Besides generally accepted risk factors of unfavorable course and outcome of the CHF patients who required hospitalization more often demonstrated impaired kidney function (79.3\%) as compared with out-patients $(55.3 \%)$. Significance of renal dysfunction as a predictor of unfavorable CHF course and outcome is no less than of other "major" factors, such as LV EF and FC of CHF. Although impaired kidney function in a greater degree predicts the all-cause mortality, it plays an important role in fatality due to progressive CHF [20]. CHF by itself was shown to promote renal hypoperfusion which results in renal vasoconstriction, blood flow redistribution and kidney function impairment with further water retention [21]. Unfortunately, up to date problem of CKD in elderly CHF patients has not been given proper attention. Taking into account renal dysfunction in aged patients with its further exacerbation by $\mathrm{CHF}$, question of medical nephroprotective treatment and general management of such patients is of great importance.

In line with high FC of CHF, low LV EF and renal dysfunction such parameter as increased level of uric acid was shown to be a marker of unfavorable CHF course. $48.8 \%$ of our patients had increased level of uric acid, which is consistent with other researchers' data [22]. So, hyperuricemia was shown to correlate with higher incidence rate of hospital admission in patients with decompensated CHF or/and with acute vascular events $[22,23]$. Our study had demonstrated that the patients of the first group revealed hyperuricemia more often (71.3\%) than those who did not require hospitalization (36.6\%; $\mathrm{p}<0.001$ ), at that average level of uric acid was 477 $\mathrm{mcmol} / \mathrm{l}$ in patients of the first group and $393 \mathrm{mc}-$ $\mathrm{mol} / \mathrm{l}$ - in the second one $(p=0.003)$. In CHF synthesis and activity of such enzyme as xanthine oxidase was found to be impaired. This results in increased production of uric acid, free radicals and superoxide anions that stimulate the oxidative stress and depress the synthesis of nitric oxide causing endothelial dysfunction. Endothelial dysfunction is one of the ways that realize the connection between $\mathrm{CHF}$ and hyperuricemia and is characterized by cell adhesive molecules expression that play an important role in vascular function maintenance [24, 25]. As a result of structural and functional changes due to endothelial dysfunction hyperuricemia is associated with adverse hemodynamic pattern: pulmonary hypertension, low cardiac index and LV EF, как предиктора неблагоприятного течения ХСН и прогноза больных также велика, как и других «больших» факторов, включая значение ФВ ЛЖ и ФК ХСН. Хотя нарушение функции почек в большей степени предсказывает общую смертность, данный фактор играет важную роль и в наступлении летального исхода от прогрессирующей ХСН [20]. Установлено, что сама по себе XСН способствует гипоперфузии почек, приводя к ренальной вазоконстрикции, перераспределению кровотока в почках и нарушению их функции с последующей задержкой жидкости в организме больных с XCH [21]. К сожалению, до настоящего времени проблеме ХБП у больных с ХСН, в частности, пожилого возраста, уделяется недостаточно внимания. В связи с тем, что у больных старших возрастных групп нарушена функция почек, а XСН ещё больше её усугубляет, возникает вопрос об особенностях как фармакотерапии, обладающей нефропротективым действием, так и тактики ведения такой категории больных в целом.

Помимо высокого ФК ХСН, низкой ФВ ЛЖ и сниженной функции почек в нашем исследовании маркером неблагоприятного течения заболевания оказался и повышенный уровень мочевой кислоты, который встречался у 48,8\% больных, что согласуется с данными других исследователей [22]. Так, при изучении у больных с декомпенсацией XСН и/или наличием острых сосудистых катастроф, частоты и выраженности гиперурикемии, последняя была связана с высокой частотой госпитализаций $[22,23]$. У наблюдавшихся нами больных, которым потребовалась госпитализация, гиперурикемия выявлялась чаще (71,3\%), чем у больных без госпитализации (36,6\%; $><0,001)$, при этом средний уровень мочевой кислоты в первой группе составил 477 мкмоль/л, во второй - 393 мкмоль/л $(p=0,003)$. При ХСН происХодит нарушение синтеза и активности фермента ксантиноксидазы. Химические процессы, осуществляемые им, приводят к повышенному образованию мочевой кислоты, свободных радикалов и супероксидных анионов, которые стимулируют оксидативный стресс и ослабляют синтез оксида азота, что негативно влияет на функцию эндотелия. Дисфункция эндотелия является одним из путей реализации взаимосвязи XСH и гиперурикемии, при которой происходит экспрессия молекул клеточной адгезии, играющих не последнюю роль в поддержании сосудистой функции, что в дальнейшем приводит к структурно-функциональным изменениям в организме [24, 25]. Как следствие этих процессов, гиперурикемия сопряжена с неблагоприятным гемодинамическим профилем: высоким давлением в лёгочной артерии, сниженными сердечным индексом, ФВ ЛЖ, коронарным кровотоком и выраженной митральной регургитацией [26-28]. В последние годы в литературе появилось достаточно большое количество исследований, рассматривающих гиперурикемию в роли маркера неблагоприятного прогноза больных с XСH $[29,30]$.

Несмотря на несомненные успехи в лечении XCH, данная патология остаётся прогностически неблагоприятной для 
decreased coronary blood flow and severe mitral regurgitation [26-28]. In recent years a lot of studies have been published, considering hyperuricemia as a marker of poor prognosis in CHF patients [29,30].

Despite apparent progress in CHF treatment this disease still has unfavorable prognosis for patients. For example, annual mortality in elderly CHF men is $14 \%$ and in women - 12\% [31]. Age of a patient is a predictor of CHF signs onset and progression. As far as last decade it was shown that CHF patients above 65 years old have higher mortality rate than younger ones [32]. We observed significant difference in survival rates of elderly CHF patients depending on necessity of hospitalization $(p<0.001)$. Lower survival rate in patients who required hospital admission can probably be explained by predominance of NYHA III-IV class CHF, low LV EF, kidney function impairment and hyperuricemia in them. This is consistent with recent ideas that CHF patients' hospitalization is a risk-factor for adverse outcome [33].

\section{Conclusion}

High FC of CHF, low LV EF, hyperuricemia and renal dysfunction play a crucial role in CHF decompensation and related hospitalization in elderly patients. Our research confirms the necessity of timely outpatient diagnosis and complex treatment of elderly patients with low LV EF, III-IV FC of CHF, renal dysfunction and hyperuricemia to decrease hospitalization rate in such patients.

Study limitations. Patients enrolled into the study were receiving outpatient care so, our results cannot completely characterize the general population of elderly CHF patients. Probably not all the factors that could have influenced CHF decompensation and related hospitalizations were taken into account.

Conflict of interest. All authors report no potential conflicts of interest that need to be disclosed in this article. больных. К примеру, годичная смертность пожилых мужчин с XСН составляет 14\%, а женщин - 12\% [31]. Возраст больного является предиктором возникновения и нарастания симптомов XСН. Ещё в прошлом десятилетии была показана более высокая смертность больных с XСН старше 65 лет, чем больных более молодого возраста [32]. Мы наблюдали существенное различие в выживаемости больных с XСH старших возрастных групп, которым потребовалась госпитализация, и без неё $(p<0,001)$. Худшая выживаемость больных, которым потребовалась госпитализация, возможно объясняется преобладанием среди них лиц с III-IV ФК XCH, сниженной ФВ ЛЖ, дисфункцией почек и гиперурикемией, что, как было представлено выше, негативно влияет на прогноз и согласуется с существующими представлениями, рассматривающими госпитализации больных с XCH как фактор риска неблагоприятного исхода [33].

\section{Заключение}

Высокий ФК ХСН, низкая ФВ ЛЖ, гиперурикемия и сниженная функция почек играют решающую роль в декомпенсации XCH и связанной с ней госпитализации пожилых больных. Полученные данные в ходе проведённого исследования свидетельствуют о том, что для снижения частоты госпитализаций пожилых больных с XCH необходимо своевременное выявление и комплексное лечение на поликлиническом этапе, особенно тех, у кого имеется низкая ФВ ЛЖ, III-IV ФК, сниженная функция почек и гиперурикемия.

Ограничения исследования. Больные, включенные в наше исследование, наблюдались в поликлинических условиях, поэтому полученные результаты не могут полностью характеризовать всю популяцию пожилых больных с XСH. При анализе данных могли быть учтены не все факторы, способные повлиять на декомпенсацию ХСН и связанную с ней госпитализацию.

Конфликт интересов. Все авторы заявляют об отсутствии потенциального конфликта интересов, требующего раскрытия в данной статье. 


\section{Литература}

1. Belenkov Yu.N., Mareev V.Yu., Ageev F.T. et al. Etiological causes of the formation of CHF in the European part of the Russian Federation (hospital phase). Serdechnaya Nedostatochnost' 2011; 6(68): 333338. Russian. (Беленков Ю.Н., Мареев В.Ю., Агеев Ф.Т. и др. Этиологические причины формирования ХСН в Европейской части Российской Федерации (госпитальный этап). Сердечная Недостаточность 2011; 6(68): 333-338)

2. National guidelines for the diagnosis and treatment of chronic heart failure (third revision). Serdechnaya Nedostatochnost' 2010; 11(57): 3-63. Russian (Национальные рекомендации по диагностике и лечению хронической сердечной недостаточности (третий пересмотр). Сердечная Недостаточность 2010; $11(57):$ 3-63)

3. Dickstein K., Cohen-Solal A., Filippatos G., McMurray J. et al. ESC Guidelines for the diagnosis and treatment of acute and chronic heart failure 2008. The Task Force for the Diagnosis and Treatment of Acute and Chronic Heart Failure 2008 of the European Society of Cardiology. Developed in collaboration with the Heart Failure Association of the ESC (HFA) and endorsed by the European Society of Intensive Care Medicine (ESICM). Eur Heart J 2008; 29:2388-2442

4. Cleland J., Cohen-Solal A., Aguilar J. et al. Management of heart failure in primary care (the IMPROVEMENT of heart Failure Programme): an international survey. Lancet 2002; 360: 1631-9.

5. Fomin I.V., Belenkov Yu.N., Mareev V.Yu. i dr. The prevalence of heart failure in the European part of the Russian Federation - the EPOHA-HSN data. Serdechnaya Nedostatochnost' 2006; 1 (35): 4-7. Russian (Фомин И.В., Беленков Ю.Н., Мареев В.Ю. и др. Распространённость ХСН в Европейской части Российской Федерации - данные ЭПОХА-ХСН. Сердечная Недостаточность 2006; 1 (35): 4-7).

6. Storozhakov G.I., Gendlin G.E. The main directions in the treatment of patients with chronic heart failure. Moscow: Miklos; 2008. Russian (Сторожаков Г.И., Гендлин Г.Е. Основные направления в лечении больных хронической сердечной недостаточностью. Москва: Миклош; 2008).

7. Hunt A., Abraham W., Chin M. et al. ACC/AHA 2005 Guidelines update for the diagnosis and management of chronic heart failure in the adult - summary article. J Am Coll Cardiol 2005; 46:111643.

8. Ross J., Chen J., Lin Z. et al. Recent national trends in readmission rates after heart failure hospitalization. Circ Heart Fail 2010;3:97-103.

9. Fang J., George A., Mensah G., et al. Heart Failure-Related Hospitalization in the U.S., 1979 to 2004. J Am Coll Cardiol 2008; 52: 428-434.

10. Zhang W., Doherty M., Pascual E. et al. EULAR evidence based recommendations for gout. Part I: Diagnosis. Report of a task force of the standing committee for international clinical studies including therapeutics (ESCISIT). Ann Rheum Dis 2006; 65:1301-1311.

11. Levey A., Coresh J., Greene T. et al. Chronic Kidney Disease Epidemiology Collaboration. Expressing the Modification of Diet in Renal Disease Study Equation for Estimating Glomerular Filtration Rate with Standardized Serum Creatinine Values. Clin Chem 2007;53(4):766-72.

12. The National Kidney Foundation KD/OQI: Clinical Practice Guidelines for chronic kidney disease: Evaluation, classification and stratification. Am J Kidney Dis 2002; 39 (Suppl.1): S1-S266.

13. Belenkov J.N., Mareev V.Y., Ageev F.T. et al. The first results of a national epidemiological study - epidemiological study of patients with CHF in real practice (referral) - the EPOHA-O-HSN study. Serdechnaya Nedostatochnost' 2003; 3 (3):116-120. Russian (Беленков Ю.Н., Мареев В.Ю., Агеев Ф.Т. и др. Первые результаты национального эпидемиологического исследования - Эпидемиологическое обследование больных ХСН в реальной практике (по обращаемости) - ЭПОХА-ОХСН. Сердечная Недостаточность 2003; 3 (3):116-120).

14. Rebrov A.P., Kosheleva N.A. Effect of therapeutic training and active outpatient management on clinical state and cardiovascular complications in patients with chronic heart failure (three year followup). Rational Pharmacother Card 2011;7(3):275-287. Russian (Ребров А.П., Н.А. Кошелева Н.А. Влияние терапевтического обучения и активного амбулаторного ведения пациентов С XСН на их клиническое состояние и сердечно-сосудистые осложнения (трехлетнее наблюдение). РФК $2011 ; 7(3): 275-287)$
15. Mirabel M., Lung B., Baron G. et al. What are the characteristics of patients with severe, symptomatic mitral regurgitation who are denied surgery? Eur Heart J 2007; 28:1358-1365.

16. Bohm M., Kilter H., Kindermann M. Mechanisms contributing to the progression of left ventricular dysfunction to end-stage heart failure. Eur Heart J Suppl 2003; 5 (Suppl 1):114-121.

17. Bursi F., Enriques-Sarano M., Nkomo Y. et al. Heart Failure and Death after myocardial infarction in the community. The emerging role of mitral regurgitation. Circulation 2005; 111: 295-301.

18. Koelling T., Aaronson K., Cody R. et al. Prognostic sighnificance of mitral regurgitation and tricuspidal regurgitation in patients with left ventricular systolic dysfunction. Am Heart J 2002; 144 (3):524-529.

19. Ngaage D., Schaff H. Mitral valve surgery in non-ischemic cardiomyopathy. J Cardiovasc Surg 2004; 45:477.

20. Serov V.A., Shutov A.M., Suchkov V.N. i dr. Effect of chronic kidney disease on prognosis of patients with chronic heart failure. Serdechnaya Nedostatochnost' 2009; 4(54): 202-204. Russian (Серов B.А., Шутов А.М., Сучков В.Н. и др. Влияние хронической болезни почек на прогноз больных хронической сердечной недостаточностью. Сердечная Недостаточность 2009; 4(54): 202-204).

21. Silva R., Nikitin N., Witte K. et al. Incidence of renal dysfunction over 6 months in patients with chronic heart failure due to left ventricular systolic dysfunction: contributing factors and relationship to prognosis. Eur Heart J 2006; 27: 569-581.

22. Hediger M., Johnson R., Miyazaki H. Molecular physiology of urate transport. Physiology 2005; 20 $125-133$.

23. Gladkikh A.S., Savina N.M., Kudinova S.P. et al. Readmissions of patients with chronic heart failure, according to a one-year follow-up. Kardiologiia 2009; (6): 31-35. Russian (Гладких А.С., Савина Н.М., Кудинова С.П. и др. Повторные госпитализации больных с хронической сердечной недостаточностью по данным одногодичного наблюдения. Кардиология 2009; (6): 31-35).

24. Leyva F., Anker S., Godsland I. et al. Uric acid in chronic heart failure: a marker of chronic inflammation. Eur Heart J 1998; 19:1814-1822.

25. Kang D., Park S., Lee I., Johnson R. Uric acid-induced C-reactive protein expression: implication on cell proliferation and nitric oxide production of human vascular cells. J Am Soc Nephrol 2005;16: 3553 3562.

26. Gullu H., Erdogan D., Caliskan M. et al. Elevated serum acid level impair coronary microvascular function in patients with idiopathic dilated cardiomyopathy. Eur J Heart Fail 2007; 9:466-468.

27. Franse L., Pahor M., Di B. et al. Serum uric acid, diuretic treatment and risk of cardiovascular events in the Systolic Hypertension in the Elderly Program (SHEP). J Hypertens 2000;18:1149-1154.

28. Larina V.N., Bart B.Ya., Brodskiy M.S. Clinical and prognostic significance of hyperuricemia in patients with chronic heart failure in elderly patients. Serdechnaya Nedostatochnost' 2011:5 (67); 277-281 Russian (Ларина В.Н., Барт Б.Я., Бродский М.С. Клиническое и прогностическое значение гиперурикемии при хронической сердечной недостаточности у больных пожилого возраста. Сердечная Недостаточность 2011: 5 (67); 277-281).

29. Wasserman A., Shnell M., Boursi B., Guzner-Gur H. Prognostic significance of serum uric acid in patients admitted to the department of medicine. Am J Med Sci. 2010; 339(1):15-21.

30. Manzano L., Babalis D., Roughton M. et al. Predictors of clinical outcomes in elderly patients with heart failure. Eur J Heart Fail 2011; 13:528-536.

31. Shafazand M., Schaufelberger M., Lappas G. et al. Survival trends in men and women with heart failure of ischaemic and non-ischemic origin: data for the period 1987-2003 from the Swedish Hospital Discharge Registry. Eur Heart J 2009; 30: 671-678.

32. Parameschwar J., Pool-Wilson P., Sutton G. Heart failure in district general hospital. J R Coll Physicians 1992: 26(2): 139-142

33. Solomon S., Dobson J., Pocock S. et al. Influence of nonfatal hospitalization for heart failure on subsequent mortality in patients with chronic heart failure. Circulation 2007; 116:1482-1487.

Received / Поступила: 07.09.2011 Accepted / Принята в печать: 11.01.2013 